\title{
De Medische Publieksacademie UMCG: medische kennis voor een breed publiek
}

\author{
J.G.M. Rosmalen, G.H. Koppelman
}

\section{Samenvatting}

Inleiding: De behoefte van het grote publiek aan medische informatie is groot. Tegelijkertijd is er veel onbetrouwbare medische informatie te vinden. Het Universitair Medisch Centrum Groningen (UMCG) heeft een Medische Publieksacademie opgericht, waarin mensen uit de algemene bevolking kosteloos medisch onderwijs gericht op leken kunnen volgen.

Opzet: De Medische Publieksacademie is georganiseerd in themaweken, met twee kernelementen. Allereerst wordt een thema ingeleid met een paginavullend artikel in het Dagblad van het Noorden, gebaseerd op interviews met medisch specialisten en wetenschappers. Daarna vindt een avondvullend programma in het UMCG plaats, waarin deskundigen uitleg geven over het klinische beeld en de stand van zaken in het wetenschappelijk onderzoek.

Resultaten: De belangstelling voor de avonden overtreft het aantal beschikbare plaatsen ruimschoots. Het publiek dat komt is zeer divers, zowel in leeftijd, opleidingsniveau als reden van bezoek. De bespreking van de thema's wordt zeer goed gewaardeerd. De Medische Publieksacademie voorziet in een behoefte. Wij willen andere universitaire medische centra dan ook stimuleren om ons voorbeeld te volgen. (Rosmalen JGM, Koppelman GH. De medische Publieksacademie UMCG: medische kennis voor een breed publiek. Tijdschrift voor Medisch Onderwijs 2011;30(5): 246-249.)

\section{Inleiding}

De honger naar medische kennis in de samenleving lijkt groot. Er zijn veel mogelijkheden om medische informatie op te doen, maar welke informatie is betrouwbaar, relevant en beschikbaar? Sinds ruim twee jaar informeert het Universitair Medisch Centrum Groningen (UMCG), in samenwerking met het Dagblad van het Noorden, actief het grote publiek over medische onderwerpen en wetenschappelijk onderzoek, via de $\mathrm{Me}$ dische Publieksacademie UMCG (MPA). In dit artikel geven we kort de achtergrond, opzet en uitvoering van de MPA weer, als ook de ervaringen van de eerste jaren. We hopen hiermee de professionals in het medisch onderwijs te informeren en te stimuleren medisch onderwijs voor een breed publiek te ontwikkelen en aan te bieden. Bij het opzet- ten van de MPA speelden verschillende overwegingen mee. Allereerst is er een groeiende behoefte aan medische informatie bij een breed publiek. Tegelijkertijd wil het UMCG verantwoording afleggen over de besteding van gemeenschapsgelden in zorg en onderzoek. Het belangrijkste doel van de MPA is dan ook om een algemeen breed publiek actief en op een toegankelijke manier te informeren over veel voorkomende aandoeningen, behandelmogelijkheden en innovaties in de geneeskunde. Ook is vertaling van wetenschappelijk onderzoek naar het grote publiek een belangrijke doelstelling. De MPA stelt een grote bevolkingsgroep in de gelegenheid kennis te nemen van nieuwe onderzoeksresultaten en ontwikkelingen. Op deze manier probeert de MPA realistische verwachtingen te scheppen over medische za- 
ken, terwijl het publiek tegelijkertijd bij het onderzoek in het UMCG wordt betrokken. Voortbouwend op de doelstellingen van medisch wetenschappelijk onderzoek, onderwijs en patiëntenzorg, draagt de MPA bij aan de ontsluiting van complexe medische kennis voor een breed publiek.

\section{Opzet van de Medische Publieksacademie}

De MPA is ontstaan uit een samenwerking tussen het UMCG en het Dagblad van het Noorden, en is opgebouwd uit themaweken. De thema's worden geselecteerd op basis van suggesties van onze bezoekers. Inmiddels melden sprekers zich ook spontaan aan met goede ideeën. Voorbeelden van thema's die aan de orde zijn gekomen zijn: hoofdpijn, depressie, overgewicht, sportblessures en borstkanker. Aan het begin van het seizoen wordt het programma in de krant en op de website gepubliceerd. Via een bon uit de krant of via de MPAwebsite kunnen deelnemers zich kosteloos inschrijven voor losse avonden of voor de gehele cyclus. De kosten van de avonden worden gedragen door het UMCG; de afdeling Communicatie neemt de organisatie voor haar rekening.

De themaweek begint met een paginagroot achtergrondartikel in de zaterdageditie van het Dagblad van het Noorden, dat is gebaseerd op een interview met clinici en wetenschappers die zich in hun werk richten op het betreffende thema. Op maandag of dinsdag volgt dan de thema-avond, waarbij twee sprekers een interactieve lezing van ongeveer drie kwartier houden. De lezingen vinden plaats in de grootste collegezaal van het UMCG met een capaciteit van 400 plaatsen. De avonden worden geleid door een voorzitter, die ook de beide sprekers introduceert. In het programma vóór de pauze komt meestal een clinicus aan het woord die het medische probleem schetst en de gevolgen voor de patiënt en de mogelijke behande- lingen. Na de pauze wordt er aandacht besteed aan het onderzoek dat in het UMCG over het betreffende probleem plaatsvindt. Op dit thema zijn variaties mogelijk. Zo was er een avond over het thema ongevallen waarbij vóór de pauze de acute opvang werd besproken en na de pauze de revalidatie-aspecten aan de orde kwamen. Bij de avond over hartinfarcten werden vóór de pauze de kortetermijneffecten en behandelingen besproken, en na de pauze de emotionele verwerking en de gevolgen voor de cardiale prognose. Een ander voorbeeld is de avond over ongewenste kinderloosheid, waar na de pauze een publieksdiscussie georganiseerd werd waarbij de deelnemers moesten stemmen op casussen die al dan niet in aanmerking zouden komen voor vruchtbaarheidsbehandelingen. Een ethicus belichtte tenslotte de ethische kant van de zaak.

Op elke avond is er ruime gelegenheid voor discussie en vragen vanuit het publiek, begeleid door de voorzitter. Bezoekers kunnen vragen stellen direct na de presentaties, en ook in de pauze een vragenkaartje invullen. De voorzitter selecteert hieruit de meest gestelde vragen, die aan het einde van de avond beantwoord worden. Na afloop van de avond blijven de sprekers altijd even in de zaal aanwezig om resterende vragen te beantwoorden. De uitgebreide mogelijkheden om vragen te stellen worden bijzonder gewaardeerd en goed benut door onze bezoekers.

\section{Waardering van de Medische Publieksacademie}

Direct al bij de start in januari 2008 bleek het initiatief een enorm succes, waarbij er alleen al voor de eerste cyclus van zes lezingen meer dan 2000 overintekeningen waren. Bij nagenoeg iedere lezing is de zaal volledig gevuld met 400 bezoekers. Inmiddels is de achtste cyclus afgerond, en nog steeds is de belangstelling meer dan het 
dubbele van het aantal beschikbare plaatsen. Iedere MPA avond is uitgebreid geëvalueerd door middel van een enquête, die door ongeveer de helft van de bezoekers aan het einde van de avond is ingevuld. Uit de enquêtes weten wij dat het publiek van de avonden zeer divers is, en afhangt van het te behandelen thema. De leeftijd varieert van onder de 20 tot boven de 80 , met een gemiddelde van ongeveer 50 jaar. Van de bezoekers heeft $10 \%$ een universitaire opleiding, 35\% een HBO-, 25\% een MBOen 30\% minder dan een MBO-opleiding. Ongeveer 20\% van de bezoekers komt omdat ze zelf de gezondheidsproblemen hebben die worden besproken, terwijl nog eens $15 \%$ een patiënt in de directe omgeving heeft en $5 \%$ beroepsmatig met het thema te maken heeft. Van de overige bezoekers komt het overgrote deel uit algemene interesse.

De kwaliteit van de avonden werd door de deelnemers met een ruime acht gewaardeerd. Een belangrijke vraag bij de opzet van de MPA was of de sprekers in staat zijn op een begrijpelijke en toegankelijke manier hun kennis over te dragen. Uit de evaluaties blijkt dat het antwoord hierop bevestigend is: het overgrote deel van de bezoekers geeft aan dat de informatie goed aansloot bij hun kennisniveau.

\section{Lessen voor de toekomst}

Gezien de populariteit en de uitstekende evaluaties kunnen wij concluderen dat de MPA voorziet in een behoefte. Wij willen andere medische centra dan ook van harte stimuleren ons voorbeeld te volgen, en zullen hiertoe dit artikel eindigen met adviezen. In onze ervaring zijn succesfactoren: 1) de kwaliteit van de sprekers, 2) voorzitters die kwaliteit en begrijpelijkheid bewaken, en 3) de samenwerking met een regionale krant met grote verspreiding in de regio.

Allereerst de kwaliteit van de sprekers. Intensieve betrokkenheid, bereidheid en enthousiasme van inhoudelijk deskundige sprekers zijn van essentieel belang voor het functioneren van de MPA. De voorzitters kiezen de beoogde sprekers uit, waarbij het belangrijkste criterium is: het vermogen om boeiend te spreken voor een lekenpubliek. Met de beide sprekers vindt altijd een voorgesprek plaats, waarbij de voorzitter uitlegt wat voor soort publiek de sprekers kunnen verwachten, en suggesties doet voor grafische en interactieve elementen in de presentatie (voor voorbeelden zie Box 1). Daarnaast dienen de sprekers een paar dagen voor de thema-avond hun presentatie aan de voorzitter voor te leggen, die de presentaties dan leest op begrijpelijkheid en eventueel suggesties doet om hier verberingen in aan te brengen (bijvoorbeeld met betrekking tot het gebruik van medisch jargon, grafieken en illustraties).

Een tweede succesfactor is de samenwerking met het Dagblad van het Noorden. Een rijk geillustreerd thema-artikel introduceert het thema van de week in de zaterdageditie; hiermee worden veel meer mensen bereikt dan mogelijk is via een lezing. Ook worden daags na de lezing reacties van bezoekers gepubliceerd in de krant. Ook incidentele kritische noten van deelnemers worden geplaatst in de krant (ingezonden brief) of op de website.

Gezien het succes van de MPA wordt gedacht over uitbreiding in de toekomst. Een wens van de organisatie is het verder uitbreiden van de mogelijkheden van de website (www.medischepublieksacademie. nl). Momenteel bevat deze website informatie over sprekers en thema's, waaronder ook de artikelen uit het Dagblad van het Noorden alsmede de presentaties van de sprekers. Een nuttige uitbreiding zou een interactief deel kunnen zijn waarin vragen over de thema's worden gesteld.

Onze ervaringen met de MPA wijzen uit dat het aanbieden van medisch onderwijs aan een breed publiek in een behoefte 
voorziet. Wij willen andere medische centra dan ook stimuleren ons voorbeeld te volgen.

\section{Box 1. Toegepaste interactieve elementen.}

- Ethische discussie met publiek over inzet van fertiliteitstechnologie

- Patiëntendemonstratie

- Stemmen op stellingen om kennis van het publiek te peilen

- Proeven en ruiken van hypoallergene zuigelingenvoeding

- Invullen van vragenlijsten om grafiekenassen beter te begrijpen

- Meten van tailleomvang

- Beoordelen van arbeidsbelasting van één van de sprekers

- Ademen door rietje met kniebuigingen om benauwdheid te ervaren

- Vervormde geluiden om slechthorendheid te ervaren
De auteurs:

Prof. dr. Judith G.M. Rosmalen, adjunct hoogleraar, Interdisciplinair Centrum voor Psychiatrische Epidemiologie, Universitair Medisch Centrum Groningen.

Prof. dr. Gerard H. Koppelman, kinderarts-pulmonoloog, Afdeling Kinderlongziekten en Kinderallergologie, Beatrix Kinderziekenhuis, Universitair Medisch Centrum Groningen.

Correspondentieadres:

Prof. dr. J.G.M. Rosmalen, ICPE, CC72, Universitair Medisch Centrum Groningen, postbus 30.001, 9700 RB Groningen. Tel: 050-3614812; fax: 050-3619722; e-mail: j.g.m.rosmalen@med.umcg.nl

Belangenconflict: geen gemeld

Financiële ondersteuning: geen gemeld

\section{Summary}

Introduction: There is an increasing demand for medical information among the general public, but the available information is not very reliable. University Medical Center Groningen launched a tuition-free medical education programme for the general public ('Medische Publieksacademie').

Design: The Medische Publieksacademie presents information about medical topics to a general lay public in a format comprising two elements: a full page article in the leading regional newspaper about a certain topic based on interviews with medical specialists and researchers, followed by an evening at University Medical Center Groningen around the same topic, where experts talk about clinical aspects and current insights from research.

Results: Attendance of the evening sessions amply exceeds the available seats. The programme attracts an audience that is highly diverse in age, education and reason for participating. The thematic presentations are very well received.

Discussion: The Medische Publieksacademie clearly meets a widely felt need. We would therefore encourage other university medical centers to follow our example. Rosmalen JGM, Koppelman GH. Groningen University Medical Center's 'Medische Publieksacademie': medical information for the general public. Netherlands Journal of Medical Education 2011;30(5):246-249.) 